\title{
Pengaruh Penggunaan Media Gambar Berseri Terhadap Keterampilan Bercerita Anak Usia 5 - 6 Tahun Di Tk ABA 06 Bromo Medan
}

Received : 18 Oktober 2020

Revised : 20 November 2020

Accepted : 24 November 2020

Nur Qomariah ${ }^{1}$, Kamtini $^{2}$

Fakultas Ilmu Pendidikan

Universitas Negeri Medan

Jln. Willem Iskandar Psr V Medan Estate

E-mail : nurqomariah@gmail.com

\begin{abstract}
Abstrak. Permasalahan dalam penelitian ini adalah: masih rendahnya minat belajar anak dalam kemampuan berbahasa terutama keterampilan bercerita dan anak cenderung pasif. Hal tersebut dikarenakan karena media pembelajaran yang digunakan guru tidak menarik perhatian anak. Penelitian ini bertujuan untuk mengetahui pengaruh penggunaan media gambar berseri terhadap keterampilan bercerita anak usia 5-6 tahun di TK Aisyiyah BustanulAthfal 06 Bromo Medan Tahun Ajaran 2015/2016.

Penelitian ini menggunakan pendekatan kuantitatif dengan desain penelitian PosttestOnly Control Group Design. Teknik pengambilan sampel dilakukan dengan random sampling, yaitu memilih sampel dengan cara acak. Cara acak/random dilakukan karena populasi anaknya di setiap kelas memiliki karakteristik yang sama dari segi usia yaitu usia 5-6 tahun. Teknik acak yang dilakukan untuk menentukan sampel kelas ekperimen yang menggunakan media gambar berseri dan sebagai kelas kontrol yaitu kelas tanpa menggunakan media gambar berseri adalah dengan cara undian. Cara undian yang dimaksud adalah dengan mengocok 2 gulungan kertas nama kelas yaitu kelas kontrol dan kelas eksperimen. Kemudian nama kelas yang keluar pertama adalah kelas eksperimen, nama yang keluar selanjutnya adalah kelas kontrol. Untuk kelas ekperimen 21 orang anak dengan pembelajaran menggunakan media gambar berseri, dan kelas kontrol 21 orang anak hanya menggunakan media gambar saja.

Hasil Analisis deskriptif menunjukkan pemanfaatan media gambar berseri lebih baik di bandingkan dari kelas kontrol. Skor tertinggi kelas eksperimen 35, kelas kontrol 28 dan skor terendah kelas eksperimen 14, kelas kontrol 13. Rata-rata kelas eksperimen 25,43 dan rata-rata untuk kelas kontrol 20,19. Jumlah anak dikelas eksperimen yang mendapat nilai di atas rata-rata lebih banyak $(38,10 \%)$ dibanding di kelas kontrol $(19,05 \%)$. Sebaliknya jumlah anak di kelas kontrol yang mendapat nilai di bawah rata-rata $(38,10 \%)$ lebih banyak dibanding di kelas eksperimen $(28,55 \%)$.

Hasil uji hipotesis diketahui t-hitung $=3,40$ lebih besar dari $\mathrm{t}$-tabel $=1,72$. Hal ini menunjukkan ada pengaruh yang signifikan penggunaan media gambar berseri terhadap keterampilan bercerita anak usia 5-6 tahun di TK Aisyiyah Bustanul Athfal 06 Bromo Medan Tahun Ajaran 2015/2016.
\end{abstract}

Kata Kunci: Keterampilan Bercerita, Media Gambar

\section{PENDAHULUAN}

Mustakim (2005:20), bercerita adalah upaya untuk mengembangkan potensi kemampuan berbahasa anak melalui pendengaran dan kemudian menuturkannya kembali dengan tujuan melatih keterampilan anak dalam bercakap- cakap untuk menyampaikan ide dalam bentuk lisan. Dengan kata lain, bercerita adalah menuturkan sesuatu yang mengisahkan suatu cerita secara lisan untuk melatih mengembangkan potensi kemampuan dalam bercerita. 
Keterampilan bercerita yang baik memerlukan pengetahuan, pengalaman serta kemampuan berpikir yang memadai. Selain itu dalam bercerita juga diperlukan penguasaan beberapa keterampilan, yaitu ketepatan tata bahasa sehingga hubungan antar kata dan kalimat menjadi jelas. Ketepatan kata dan kalimat sangat perlu dikuasai dalam bercerita, sebab dengan menggunakan kata dan kalimat yang tepat dalam bercerita akan memudahkan pendengar memahami isi cerita yang dikemukakan oleh pembicara. Isi cerita yang mudah dipahami akan menunjang dalam penyampaian maksud yang sama antara pembicara dan pendengar, sehingga tujuan penyampaian makna cerita juga dapat tercapai. Selain itu dalam bercerita diperlukan kelancaran dalam menyampaikan kalimat perkalimat.

Untuk mengembangkan keterampilan bercerita pada anak usia dini, dalam penelitian ini menggunakan media agar dapat lebih menarik dan menyenangkan untuk anak karena dalam pembelajaran anak usia dini dengan belajar sambil bermain.

Media pembelajaraan anak usia dini digolongkan menjadi tiga macam yaitu media audio, media visual, dan audiovisual. Dalam penelitian ini untuk mengembangkan keterampilan bercerita anak usia 5- 6 tahun, media yang digunakan adalah gambar berseri. Media gambar berseri merupakan media visual yang berisi urutan gambar, antara gambar satu dengan yang lain saling berhubungan dan menyatakan suatu peristiwa. Media ini digunakan untuk memperjelas penyajian materi, meningkatkan motivasi belajar anak, anak terlibat secara langsung dalam pembelajaran sehingga pembelajaran akan lebih bermanfaat dan bermakna. Diharapkan dengan gambar berseri ini anak belajar tidak hanya melihat gambarnya saja, tetapi juga mendengar dan menceritakan gambar berseri secara berurutan. Semua itu akan memotivasi anak untuk belajar secara aktif dan menyenangkan merangsang daya pikir anak agar mampu menuangkan ide, gagasan dalam keterampilan bercerita anak.

Pembelajaran dengan menggunakan media gambar berseri merupakan konsep belajar yang dapat membantu guru dalam mengaitkan materi yang diajarkan dengan situasi yang nyata anak dan mengungkapkan pengalaman dan pengertian yang lebih luas, lebih jelas tidak mudah dilupakan serta lebih konkrit dalam ingatan.

Dengan menggunakan media gambar berseri anak akan lebih terampil dalam mengungkapkan pengalaman dalam bentuk bercerita dan diharapkan dapat mengurangi kejenuhan anak dalam pembelajaran berbahasa yaitu keterampilan bercerita. Dengan menggunakan media gambar berseri juga akan memudahkan anak untuk mencapai tujuan dalam terampil bercerita yaitu mengungkapkan apa yang dia lihat dalam media gambar tersebut, dengan mengucapkan kata-kata dengan jelas, lancar dan tepat dan membuat kalimat sederhana. Jadi, media gambar berseri merupakan sarana proses pembelajaran untuk mempertinggi efektivitas dan efisiensi dalam mencapai tujuan pembelajaran.

\section{METODOLOGI PENELITIAN}

Metode penelitian yang digunakan dalam penelitian ini adalah metode penelitian eksperimen.Desain dalam penelitian ini adalah True Eksperimental Design, dengan bentuk Postest-Only Control Design dalam model ini terdapat kelompok eksperimen dan kelompok Kontrol yang dipilih secara random. Sugiyono (2010:117) mengatakan populasi adalah wilayah generalisasi yang terdiri atas : objek/subjek yang mempunyai kualitas dan karakteristik tertentu yang ditetapkan peneliti untuk dipelajari dan kemudian 
ditarik kesimpulannya. Dari definisi diatas, maka Populasi dalam penelitian adalah 44 anak 2 kelas kelompok B yang berusia 5-6 tahun di TK AISYIYAH BUSTANUL ATHFAL 06 Bromo Medan.

Dalam penelitian ini teknik pengumpulan data yang digunakan adalah observasi. Metode observasi dilakukan dengan cara mengamati dan mencatat semua aktivitas anak pada proses kegiatan kolase di kelas. Observasi dilakukan pada anakkelompok Buntuk memperoleh data anak yang berkaitan dengan aspek-aspek kreativitas anak.Penyusunan data dilakukan dengan memuat namaanak.Tugas observer memberi tanda checklist $(\checkmark)$ pada skor yang di dapat melalui pedoman observasi yang dibuat. Dari observasi yang dilakukan maka diperoleh data tentang pengaruh keterampilan bercerita menggunankan media gambar berseri

Tabel.1. Tabel Kisi-Kisi Pedoman Observasi Keterampilan Bercerita

\begin{tabular}{|c|c|c|c|c|c|}
\hline \multirow{2}{*}{ Dimensi } & \multirow{2}{*}{ Indikator } & \multirow{2}{*}{ Kreteria Penilaian } & \multicolumn{3}{|c|}{ Skala Penilaian } \\
\hline & & & 12 & 3 & 4 \\
\hline \multirow{16}{*}{$\begin{array}{l}\text { 1.Aspek } \\
\text { Kebahasaan }\end{array}$} & \multirow[t]{4}{*}{ 1. Kejelasan vocal } & 1. Kurang jelas & & & \\
\hline & & 2. Cukup jelas & & & \\
\hline & & 3. jelas & & & \\
\hline & & 4. sangat jelas & & & \\
\hline & \multirow[t]{4}{*}{ 2. Ketepatan intonasi } & 1. kurang tepat & & & \\
\hline & & 2. cukup tepat & & & \\
\hline & & 3. tepat & & & \\
\hline & & 4. sangat tepat & & & \\
\hline & \multirow{4}{*}{$\begin{array}{l}\text { 3. Ketepatan pilihan } \\
\text { kata (diksi) }\end{array}$} & 1. kurang tepat & & & \\
\hline & & 2. cukup tepat & & & \\
\hline & & 3. tepat & & & \\
\hline & & 4. sangat tepat & & & \\
\hline & \multirow[t]{4}{*}{ 4. struktur kalimat } & 1. kurang sempurna & & & \\
\hline & & 2. cukup sempurna & & & \\
\hline & & 3. sempurna & & & \\
\hline & & 4. sangat sempurna & & & \\
\hline \multirow{13}{*}{$\begin{array}{l}\text { 2. Aspek Non } \\
\text { Kebahasaan }\end{array}$} & \multirow[t]{4}{*}{ 5. Kelancaran Bercerita } & 1. kurang lancar & & & \\
\hline & & 2. cukup lancar & & & \\
\hline & & 3. lancar & & & \\
\hline & & 4.sangat lancar & & & \\
\hline & \multirow[t]{4}{*}{ 6. Penguasaan Materi } & 1. kurang menguasai & & & \\
\hline & & 2. cukup menguasai & & & \\
\hline & & 3. menguasai & & & \\
\hline & & 4. sangat menguasai & & & \\
\hline & \multirow{4}{*}{$\begin{array}{ll}\text { 7. } & \text { Kontak Mata } \\
\text { dengan Pendengar }\end{array}$} & 1. tidak menatap & & & \\
\hline & & 2. jarang menatap & & & \\
\hline & & 3.sering menatap & & & \\
\hline & & 4. selalu menatap & & & \\
\hline & 8. Ketertiban & 1. kurang tertib & & & \\
\hline
\end{tabular}




\begin{tabular}{|c|c|}
\hline & 2. cukup tertib \\
\hline & 3. tertib \\
\hline & 4. sangat tertib \\
\hline 9. Keberanian & 1. kurang berani \\
\hline & 2. cukup berani \\
\hline & 3.berani \\
\hline & 4. sangat berani \\
\hline 10. Semangat & 1. kurang semangat \\
\hline & 2. cukup semangat \\
\hline & 3. semangat \\
\hline & 4. sangat semangat \\
\hline
\end{tabular}

\section{HASIL DAN DISKUSI}

Telah diterangkan sebelumnya pada bab III bahwa dalam penelitian ini dikumpulkan dengan teknik observasi. Lembar observasi telah disusun sehingga dapat digunakan untuk melihat data perkembangan kreativitas anak.

Dari observasi, dapat dilihat bahwa dengan kegiatan membatik memberikan perbedaan pada perkembangan kreativitas anak di kelas kontrol dan kelas eksperimen. Perbedaan tersebut dapat dilihat dalam tabel dibawah ini

Tabel 2. Hasil Hipotesis dengan Uji-T

\begin{tabular}{|c|c|c|c|c|c|}
\hline No & Kelas & $\begin{array}{l}\text { Nilai Rata- } \\
\text { rata }\end{array}$ & $t_{\text {hitung }}$ & $t_{\text {tabel }}$ & Keterangan \\
\hline 1 & Eksperimen & 25,43 & & & Ada perbedaan yang \\
\hline 2 & Kontrol & 20,19 & 3,40 & 1,72 & signifikan \\
\hline
\end{tabular}

Dari hasil perhitungan diperoleh nilai $t_{\text {hitung }}=3,40$ dibandingkan dengan nilai $t_{\text {tabel }}=$ 1,72 dengan $\left(\mathrm{dk}=\left(n_{1}+n_{2}\right)-2=40\right.$ dan taraf $\left.\alpha=0,05\right)$. Nilai $t_{\text {tabel }}$ dengan taraf $\alpha=$ 0,05 diperoleh 1,72. Sehingga diperoleh $t_{\text {hitung }}=3,40>t_{\text {tabel }}=1,72$, maka $\mathrm{H}_{0}$ ditolak dan $\mathrm{H}_{\mathrm{a}}$ diterima, jadi dapat dinyatakan "Ada pengaruh penggunaan media gambar berseri terhadap keterampilan bercerita anak usia 5-6 Tahun di TK Aisyiyah Bustanul Athfal 06 Bromo Medan T.A 2015/ 2016.

\section{PEMBAHASAN}

Hasil pada penelitian ini menunjukkan bahwa dengan menggunakan media gambar berseri dapat berpengaruh dengan keterampilan bercerita anak karena terlihat jelas bahwa perbandingan nilai rata- rata anak di kelas eksperimen lebih tinggi yaitu 25,43 dibandingkan dengan nilai rata- rata anak di kelas kontrol yaitu 20,19 dan ada perbedaan yang signifikan dengan menggunakan media gambar berseri dan tanpa menggunakan media gambar berseri. Penggunaan media gambar berseri membuat anak semangat untuk menceritakan gambar satu ke gambar yang berikutnya karena anak tertarik dengan media gambar yang berwarna warni sehingga dapat melatih dan mempertajam imajinasi pada anak. Dengan melihat gambar berseri, anak bisa menyampaikan gambar yang dilihatnya dengan menceritakan gambar secara berurut dan bahasa yang jelas.

Menurut Sapari (dalam Hasnindah, 2011: 8), mengemukakan bahwa media gambar seri merupakan serangkaian gambar yang terdiri dari 2 hingga 6 gambar yang menceritakan 
suatu kesatuan cerita yang dapat dijadikan alur pemikiran siswa dalam mengarang, setiap gambar dapat dijadikan paragraf. Dapat dikatakan bahwa dengan penggunaan media gambar berseri dapat dijadikan sebagai solusi untuk memandu anak agar dapat menceritakan gambar yang dilihatnya secara berurut dan menyampaikan cerita dengan bahasa yang jelas.

Dengan demikian, dalam penelitian ini gambar berseri berpengaruh terhadap keterampilan bercerita karena dengan melihat gambar berseri anak dapat mengisahkan cerita secara lisan dengan berurut dan bahasa yang jelas, dapat membantu proses berpikir anak, membimbing anak, untuk menyebutkan unsur-unsur dalam cerita misalnya tokoh,setting, dan alur cerita.

\section{SIMPULAN}

Berdasarkan hasil penelitian dan pengolahan data pada sub bab sebelumnya dapat di ambil kesimpulan, yaitu :

1. Media Gambar berseri adalah gambar yang mempunyai urutan kejadian yang memiliki satu kesatuan cerita. keterampilan bercerita anak dapat dikembangkan melalui pembelajaran yang menggunakan media gambar berseri karena akan mempengaruhi keterampilan anak dengan cara melihat gambar berseri kemudian menceritakan dan mengaitkan satu gambar ke gambar yang selanjutnya dengan berurut dan bahasa yang jelas.

2. Uji persyaratan analisis untuk normalitas dengan Lilliefors untuk kelas eksperimen diketahui $L_{0}=0,059$ adalah lebih kecil dari $L_{\text {tabel }}$ sebesar 0,190. Untuk kelas kontrol diketahui $L_{0}=0,052$ adalah lebih kecil dari $L_{\text {tabel }} 0,190$. Uji homogenitas varians data keterampilan bercerita anak dari kedua kelas hasil penelitian berasal dari populasi yang homogen. nilai $\mathrm{F}_{\text {hitung }}=1,49<\mathrm{F}_{\text {tabel }}=2,12$.

3. Hasil uji hipotesis menunjukkan ada pengaruh yang signifikan penggunaan media gambar berseri terhadap keterampilan bercerita anak usia 5-6 tahun di TK Aisyiyah Bustanul Athfal 06 Bromo Medan. Hasil uji dua rata-rata diketahui t-hitung $=3,40$ lebih besar dari $\mathrm{t}$-tabel $=1,72$.

Berdasarkan kesimpulan diatas, maka peneliti mengajukan beberapa saran yaitu :

1. Bagi kepala sekolah hendaknya menghimbau dan member kesempatan kepada Guru agar lebih kreatif dalam membuat media gambar dan menggunakan media gambar berseri dalam pembelajaran bahasa terutama keterampilan bercerita. Dengan bercerita , anak akan menyalurkan kebutuhan imajinasi dan fantasi sehingga dapat memperluas wawasan dan cara berfikir anak sekaligus menanamkan pesan pesan atau nilai- nilai sosial, moral dan agama yang terkandung dalam sebuah cerita.

2. Peneliti lain sebagai bahan dan sumber referensi bagi peneliti berikutnya yang melakukan penelitian yang ada hubungannya dengan penelitian ini.

3. Kepala sekolah sebagai masukan dan bahan pertimbangan kepada para guru-guru agar dapat lebih mengasah kemampuan dan kreatifitas dalam membuat media gambar berseri.

\section{DAFTAR RUJUKAN}

Abbas, Hasnindah. 2011. Meningkatkan Hasil Belajar Bahasa Indonesia Keterampilan Menulis Materi Membuat Karangan Melalui Media Gambar Seri pada Murid Kelas V SDN Sudirman III Makassar. Jurnal. Makassar: FIP UNM.

Adin. (2015). Asyiknya Mendongeng!.Yogyakarta: Citra Media Pustaka. 
Amirullah, Hari. (2003). Alat Evaluasi Keterampilan Bermain Bola Basket : Jurnal

Nasional Pendidikan Jasmani dan Ilmu Keolahragaan. Jakarta: Depdiknas.

Arikunto, Suharsimi. (2009). Prosedur Penelitian suatu Pendekatan Praktik. Jakarta: Rineka Cipta

Arsyad, Azhar . (2015).Media Pembelajaran. Jakarta: Raja Grafindo Persada.

Arsyad, dan Mukti U.S. (1993). Pembinaan Kemampuan Berbicara Bahasa Indonesia. Jakarta : Erlangga.

Bachri, Bachtiar S. (2005). Pengembangan Kegiatan Bercerita, Teknik \&Prosedurnya. Jakarta : Depdikbud.

Daryanto. (2002). Media Pembelajaran. Yogyakarta: Gava Media.

Dhieni, Nurbiana dkk. 2005.Metode Pengembangan Bahasa. Jakarta: UniversitasTerbuka

Fadlillah, Muhammad. (2012). Desain Pembelajaran PAUD: Tinjauan Teoretik \& Praktik. Jogjakarta: Ar-Ruzz Media.

Tarigan, Henry Guntur. (1981). Berbicara sebagai Suatu Keterampilan Berbahasa. Bandung: Angkasa.

Mudini \& Purba Salamat. (2009).Pembelajaran Berbicara. Jakarta: Depdiknas.

Mulyati, Yetti dkk. (2009). Bahasa Indonesia. Jakarta: Universitas Terbuka

Musfiroh, Tadkiroatun. (2008). Memilih, Menyusun, dan Menyajikan Cerita untuk Anak Usia Dini. Yogyakarta: Tiara Wacana.

Mustakim, M Nur (2005). Peranan Cerita Dalam Pembentukan Perkembangan Anak TK.Jakarta : Depdiknas

Nurgiyantoro, Burhan. (2009). Penilaian dalam Pengajaran Bahasa dan Sastra. Yogyakarta: BPFE

Permana, Yanto. 2005. "Mengembangkan Kemampuan Penalaran dan Koneksi Matematik Siswa SMA Melalui Pembelajaran Berbasis Masalah".http://www.pagesyourfavorite.com//PPSUPI/ Abstrakmat 2005. html. Diakses tanggal 12 Maret 2016.

Risaldy, Sabil. (2014). Bermain, Bercerita \& Menyanyi Bagi Anak Usia Dini. Jakarta: PT.Luxima Metro Media. Cetakan II.

Sadiman, Arief dkk. (2008). Media Pendidikan. Jakarta: Raja Grafindo Persada.

Sudjana, N. (2006). Metode Statistik. Bandung. Tarsito

Sugiyono. (2012). Metode Penelitian Kuantitatif, Kualitatif, $R \& D$.Bandung: Alfabeta

Sukardi. (2013). Metode Penelitian Pendidikan Kompetensi dan Praktiknya. Jakarta: PT Bumi Aksara

Syah, Muhibbin. (2006). Psikologi Belajar. Jakarta: PT Raja Grafindo Persada 